\title{
RESPONSE TO DROUGHT OF SOME WILD SPECIES OF Helianthus AT SEEDLING GROWTH STAGE
}

\author{
Onemli, F. ${ }^{*}$, Gucer, T. ${ }^{2}$ \\ ${ }^{1}$ University of Namik Kemal, Faculty of Agriculture, \\ Department of Field Crops, 59030 Tekirdag, Turkey \\ 2 Thrace Agricultural Research Institute, Edirne, Turkey
}

Received: April 10, 2010

Accepted: August 10, 2010

SUMMARY

Response of six wild sunflower genotypes including Helianthus petiolaris spp. petiolaris (E-142), Helianthus neglectus (E-017) and Helianthus annuus (E-060, E-173, E-174 and E-175) to drought stress imposed at the seedling growth stage was investigated in vivo. Plant height, number of leaves per plant, shoot fresh weight, root fresh weight, shoot dry weight and root dry weight were determined. Results indicated that the E-175 genotype belonging to Helianthus annuus was less affected by water stress conditions as compared to the other genotypes. Helianthus petiolaris spp. petiolaris (E-142) showed the highest sensitivity and had the lowest fresh and dry masses under drought conditions. In addition, this study showed that the number of leaves and root weight were the best selection criteria to determine drought resistance at the early vegetative stage. Water losses of the resistant genotypes in their roots and shoots in drought stress conditions were more than those of the sensitive genotypes.

Key words: Helianthus, $H$. petiolaris, $H$. neglectus, $H$. anuus, drought

\section{INTRODUCTION}

Sunflower (Helianthus annuus) is one of the most important oil crops in the world. It is grown in a number of countries on marginal soils, generally in semi-arid conditions acting as a limiting factor in crop production.

Limited rainfall or shortage of water for irrigation during the growing season restricts sunflower seed yields with significant reductions.

Due to the specific structure of its main organs (root, stem, leaves, head), sunflower can be successfully grown on marginal soils and in semi-arid conditions and is more resistant to abiotic stresses than other field crops (Kiani et al., 2007; Škorić, 2009).

* Corresponding author: e-mail: fonemli@nku.edu.tr 
However, some authors categorize sunflower as a low to medium drought sensitive crop (Fereres et al., 1986; Fick and Miller, 1997; Reddy et al., 2003; Iqbal et al., 2005; Rauf, 2008).

Drought is the most limiting of all abiotic stresses and it affects well over one third of the soils worldwide. Plants that manage to survive the effects of drought stress show a decrease in fertility, yield and product quality. Drought also causes yield variations from year to year and thus affects yielding stability (Monti, 1986). It has a vital role in plant growth and development at all growth stages. However, depending upon plant species, certain stages such as germination, seedling or flowering could be the most critical stages for water stress (Ashraf and Mehmood, 1990; Albuquerque and Carvalho, 2003).

Drought can be managed to minimize its deleterious effects. Agronomically, the best approach for the management of drought stress is to irrigate the field (Edmeades and Bänziger, 1997; Bošnjak, 2004; Rauf, 2008). Other drought management techniques include the use of mulches to reduce evaporation losses, better weed control, crop rotations, improved cultivation methods to enhance infiltration rate, foliar sprays, and efficient irrigation practices (Gajri et al., 1997; Rauf, 2008). A basic philosophy for all these management practices is to relieve the deleterious effects of drought and to use the water efficiently. However, the above mentioned agronomic practices increase the costs and are dependent on input availability, infrastructure, access to market and skills in crop and soil management (Campos et al., 2004; Rauf, 2008). Drought can also be managed by modifying plant morphology or by incorporating some traits that will help plants cope with drought stress successfully (Yordanov et al., 2000; Rauf, 2008). Thus, genetic modification is usually the most successful and cheapest strategy to cope with drought. Since modifications within plant morphology and physiology introduced through breeding are heritable, once they are introduced into a set of breeding materials they become a permanent source of drought tolerance.

There are numerous strategies utilized in breeding for drought stress in a crop species such as the induction of earliness for drought escape, modification of certain plant traits that leads toward drought resistance, and introduction of drought tolerant traits associated with high yield. Drought resistance may be defined as mechanism(s) causing minimum loss of yield in a drought environment. In sunflower breeding for resistance to abiotic stresses, the greatest progress has been made in selection for drought resistance. Therefore, growing of drought tolerant cultivars will contribute to more stable sunflower production and the screening of the response of sunflower cultivars or breeding lines to drought stress can play a crucial role in breeding programmes. Breeding for resistance to drought and high temperatures is an important objective in many sunflower programs. Several types of germplasm are used in sunflower breeding for drought resistance, such as landraces, cultivated hybrids and varieties; wild species of the genus Helianthus, and genetically engineered germplasm (Rauf, 2008; Škorić, 2009). 
The best results in increasing the drought resistance of cultivated sunflower have been achieved using wild species of the genus Helianthus. The diversity of the wild Helianthus species offers great possibilities for increasing the genetic resistance of the cultivated sunflower towards abiotic stresses. In using wild sunflower species in sunflower breeding for drought resistance, the best results have so far been achieved with Helianthus argophyllus, Helianthus anomalus and Helianthus deserticola (Baldini et al., 1999; Seiler, 2004; Škorić, 2009). Wild species are readily classifiable as "water savers" and "water spenders" (Reddy et al., 2003). According to Korrell et al. (1997), wild sunflower contains considerable variability for tolerance of abiotic stresses like drought. Wild species are a potentially important source of abiotic tolerance; therefore, it may be desirable to introgress drought tolerant genes from wild relatives. The genus Helianthus is comprised of 51 species and 19 subspecies with 14 annual and 37 perennial species (Seiler, 2007). Sunflower breeders worldwide should commit to a greater use of wild Helianthus species in breeding for resistance to abiotic stresses (Singh, 2000; Rauf, 2008).

Evolving crop genotypes which have enhanced drought tolerance is the most successful and cheapest strategy to cope with drought. The present study was conducted with the objectives to determine the response of some wild Helianthus species to drought stress at seedling stages.

\section{MATERIALS METHODS}

The present study was carried out in a controlled glasshouse of the Trakya Agricultural Institute in 2008. Pots with a capacity of $7.5 \mathrm{~kg}$ containing sand, peat compost and field soil in 1:1:1 ratio were used for growing media. Six wild Helianthus genotypes belonging to three species (Helianthus neglectus (E-017), Helianthus petiolaris spp. petiolaris (E-142) and four genotypes of Helianthus annuus (E-060, E-173, E-174 and E-175)) were evaluated for their resistance to water stress.

The experiment was conducted in a randomized block design with four replications. The main plots consisted of three water stress treatments. These were $25 \%$, $75 \%$ and $100 \%$ (control) of the amount of water held at field capacity of soils in all pots, field capacity meaning the amount of water held by soil against gravity defined according to Bilski et al. (1988).

These trials were hand seeded with three to four seeds into pots. At the four to six leaf stage, plants were thinned to one plant per pot. In the beginning, all plots were well watered in order to obtain good germination. After thinning, the water stress treatments were applied into pots during four weeks. For determining the drought stress of wild Helianthus, we used some seedling traits. These were plant height (g), shoot fresh weight (g), root fresh weight (g), shoot dry weight (g), and root dry weight (g). 
Analysis of variance of the data was computed using the JMP program (JMP software-data analysis statistics, 2005). The least significant difference (LSD) test at $5 \%$ level of probability was used to determine the differences among values. In addition, the correlations among traits were analyzed. Relative tolerance was calculated for each genotype and different drought levels using the following formula (Turhan and Baser, 2004):

Relative tolerance $(\%)=\frac{\text { Absolute value }}{\text { Value at } 0.00 \% \text { drought level }} \times 100$

\section{RESULTS AND DISCUSSION}

The results were observed for six plant characters taken from six wild genotypes belonging to three different Helianthus species under different water stress conditions. The treatments were $100 \%, 75 \%$ and $25 \%$ of the amount of water held at field capacity. The wild Helianthus species evaluated were $H$. petiolaris spp. petiolaris (E-142), Helianthus neglectus (E-017) and Helianthus annuus (four genotypes: E-060, E-173, E-174 and E-175).

The results obtained in the in vivo trial showed that the effect of drought on all characters, genotypes and their interactions was significant. Under water stress conditions, plant growth was dramatically reduced. The means for each treatment by LSD are shown in Table 1. According to the results, when field capacity was kept at the $75 \%$ level, shoot dry weight and root dry weight were affected more than the other characters. In the other drought treatment at $25 \%$ field capacity, root fresh weight declined by $88 \%$ of the value at the 0.00 drought level. The second most affected character of wild sunflower genotypes by drought was shoot fresh weight.

In the control treatment, the highest plant height was observed in E-060 and E173. The highest number of leaves was found in E-175, E-174 and E-173, while E142 had the lowest number of leaves. For shoot fresh weight, all genotypes except E-142 were in the same group. E-142 also had the lowest root fresh weight. E-175 had the highest dry shoot weight at $100 \%$ field capacity of soil. E-175 was also in the first group for dry root weight with E-173.

In the condition of $75 \%$ field capacity, plant height of E-142 was the lowest, while the other genotypes were in the other group. E-142 also had the lowest relative tolerance for this character. For the number of leaves at this drought level, E175 was in the first group, while E-142 and E-060 had the lowest number of leaves. At the same time the highest relative tolerance for the number of leaves was calculated for E-175. The highest shoot fresh weight and relative tolerance were observed in E-017. At this drought level, the shoot fresh weight of E-017 was not affected by stress at the $5 \%$ statistical level. However, E-142 had the lowest root fresh weight and the highest relative tolerance for this character.

At $75 \%$ field capacity, the lowest root dry weight and relative tolerance were found in E-142 and E-060, while E-173 and E-175 had the highest root dry weight. 
Table 1: Plant character measurements and relative tolerance to drought during the vegetative period of six wild sunflower genotypes under different water stress treatments in vivo

\begin{tabular}{|c|c|c|c|c|}
\hline \multirow[t]{2}{*}{ Helianthus species } & \multicolumn{4}{|c|}{ Drought level (\%) } \\
\hline & Control (100) & 75 & 25 & Mean \\
\hline Helianthus annuus (E-60) & $18.04 a(100)$ & $12.12 \mathrm{e} \quad(67)$ & 4.67gh (26) & $11.61 \mathrm{a}^{\star}$ \\
\hline Helianthus annuus (E-173) & $16.25 a b \quad(100)$ & 12.81 de (79) & $3.47 \mathrm{~h} \quad(21)$ & $10.84 a b$ \\
\hline Helianthus annuus (E-174) & $15.06 \mathrm{bc} \quad(100)$ & 12.07 e (80) & $3.94 \mathrm{gh} \quad(26)$ & $10.35 \mathrm{~b}$ \\
\hline Helianthus annuus (E-175) & $14.32 \mathrm{bcd}(100)$ & 11.82 e (82) & $5.84 \mathrm{~g} .(40)$ & $10.66 \mathrm{~b}$ \\
\hline Helianthus neglectus (E-017) & $15.11 \mathrm{bc} \quad(100)$ & $12.58 \mathrm{de}(83)$ & $3.98 \mathrm{gh}(26)$ & $10.55 a b$ \\
\hline H. petiolaris spp. petiolaris $(\mathrm{E}-142)$ & 2) $13.48 \mathrm{cde}(100)$ & $8.51 f \quad(63)$ & $3.13 \mathrm{~h}$ & $8.38 \mathrm{c}$ \\
\hline Plant height $(\mathrm{cm})$ & Relative tolerance (\% & Mean Squ & are: $3.703^{*}$ & $\operatorname{LSD}_{0.05}: 1.14$ \\
\hline Helianthus annuus (E-60) & $9.41 \mathrm{~cd}(100)$ & $6.50 \mathrm{fg}(69)$ & $2.50 \mathrm{j} \quad(27)$ & $6.13 d$ \\
\hline Helianthus annuus (E-173) & $10.66 \mathrm{a} \quad(100)$ & $5.75 \mathrm{~h} \quad(54)$ & $3.16 \mathrm{j} \quad(30)$ & $6.52 \mathrm{~cd}$ \\
\hline Helianthus annuus (E-174) & $10.50 \mathrm{ab} \quad(100)$ & $8.41 \mathrm{e} \quad(80)$ & $3.16 \mathrm{j} \quad(30)$ & $7.36 \mathrm{~b}$ \\
\hline Helianthus annuus (E-175) & $10.50 \mathrm{ab} \quad(100)$ & 8.91 de (85) & $4.00 \mathrm{i} \quad(38)$ & $7.80 \mathrm{a}$ \\
\hline Helianthus neglectus (E-017) & $9.83 \mathrm{bc}(100)$ & $7.08 \mathrm{f} \quad(72)$ & $2.91 \mathrm{j} \quad(30)$ & $6.61 \mathrm{c}$ \\
\hline H. petiolaris spp. petiolaris $(\mathrm{E}-142)$ & 8.50 e (100) & 5.91gh (70) & $2.50 \mathrm{j} \quad(29)$ & $5.63 \mathrm{e}$ \\
\hline Number of leaves & Relative tolerance (\%) & Mean Squ & re: $1.281^{\star *}$ & $\operatorname{LSD}_{0.05}: 0.40$ \\
\hline Helianthus annuus (E-60) & 13.53abc (100) & 9.70cde(72) & $\begin{array}{ll}2.26 \mathrm{e} & (54)\end{array}$ & $10.16 \mathrm{a}$ \\
\hline Helianthus annuus (E-173) & $14.67 a b \quad(100)$ & $10.32 \mathrm{cde}(70)$ & $2.04 f \quad(14)$ & $9.01 a$ \\
\hline Helianthus annuus (E-174) & 12.93abcd(100) & 9.13de (71) & $1.70 f$ & 7.92ab \\
\hline Helianthus annuus (E-175) & $15.35 a$ & $10.18 \mathrm{cde}(66)$ & $2.40 f$ & $9.31 \mathrm{a}$ \\
\hline Helianthus neglectus (E-017) & $15.74 a$ & 12.88abcd(82) & $1.34 f$ & $9.99 a$ \\
\hline H. petiolaris spp. petiolaris $(\mathrm{E}-142)$ & 2) $10.79 \mathrm{bcde}(100)$ & $7.53 \mathrm{e} \quad(70)$ & $0.92 f$ & $6.41 \mathrm{~b}$ \\
\hline Shoot fresh weight $(\mathrm{g})$ & Relative tolerance (\% & Mean S & uare: 8.791 & $\operatorname{LSD}_{0.05}: 2.36$ \\
\hline Helianthus annuus (E-60) & $24.89 a \quad(100)$ & $19.83 \mathrm{~cd}(80)$ & $2.44 g \quad(10)$ & $15.72 a$ \\
\hline Helianthus annuus (E-173) & $21.18 \mathrm{bc}(100)$ & 14.30 ef (69) & $2.09 \mathrm{~g} \quad(15)$ & 12. \\
\hline Helianthus annuus (E-174) & $21.95 b \quad(100)$ & $17.97 d \quad(82)$ & $2.30 \mathrm{~g} \quad(10)$ & $7 \mathrm{bc}$ \\
\hline Helianthus annuus (E-175) & $22.30 \mathrm{~b} \quad(100)$ & $18.58 d \quad(83)$ & $3.23 \mathrm{~g} \quad(14)$ & $0 a b$ \\
\hline Helianthus neglectus (E-017) & $22.05 b \quad(100)$ & $15.86 e \quad(72)$ & $2.34 \mathrm{~g}$ & $13.41 \mathrm{~cd}$ \\
\hline H. petiolaris spp. petiolaris $(\mathrm{E}-142)$ & $15.78 \mathrm{e} \quad(100)$ & $13.19 f \quad(87)$ & $1.89 \mathrm{~g} \quad(12)$ & $10.29 \mathrm{e}$ \\
\hline Root fresh weight $(\mathrm{g})$ & Relative tolerance (\%) & Mean Sq & are: 7.847 ** & $\operatorname{LSD}_{0.05}: 1.08$ \\
\hline Helianthus annuus (E-60) & $4.30 \mathrm{c}$ & 2.12gh (49) & $0.47 \mathrm{k} \quad(11)$ & $2.29 \mathrm{c}$ \\
\hline Helianthus annuus (E-173) & $5.19 b$ & $3.35 \mathrm{e} \quad(65)$ & $1.27 \mathrm{j}$ & $3.26 \mathrm{~b}$ \\
\hline Helianthus annuus (E-174) & $3.85 d$ & $2.32 \mathrm{~g} \quad(60)$ & $1.00 \mathrm{j}$ & $2.40 \mathrm{c}$ \\
\hline Helianthus annuus (E-175) & $5.49 b$ & $2.88 f$ & 1.93hi (35) & 3.43ab \\
\hline Helianthus neglectus (E-017) & $6.30 \mathrm{a}$ & $3.51 \mathrm{e} \quad(56)$ & $1.03 \mathrm{j}$ & $3.60 a$ \\
\hline H. petiolaris spp. petiolaris $(\mathrm{E}-142)$ & 2.04ghi (100) & $1.77 \mathrm{i}$ & $0.39 \mathrm{k} \quad(19)$ & $1.40 \mathrm{~d}$ \\
\hline Shoot dry weight (g) & Relative tolerance (\%) & ) Mean Sq & are: 1.322 & $\operatorname{LSD}_{0.05}: 0.18$ \\
\hline Helianthus annuus (E-60) & $1.08 \mathrm{~d}$ & $0.49 f \quad(45)$ & $0.14 \mathrm{~h} \quad(13)$ & $0.57 \mathrm{c}$ \\
\hline Helianthus annuus (E-173) & $1.76 \mathrm{a}$ & $1.32 \mathrm{bc}(75)$ & $0.42 \mathrm{fg} \quad(24)$ & $1.16 \mathrm{a}$ \\
\hline Helianthus annuus (E-174) & $1.43 b$ & $1.06 \mathrm{~d} \quad(74)$ & $0.34 \mathrm{~g} \quad(24)$ & $0.94 b$ \\
\hline Helianthus annuus (E-175) & $1.71 \mathrm{a}$ & $1.22 \mathrm{c} \quad(71)$ & $0.71 \mathrm{e} \quad(42)$ & $1.21 \mathrm{a}$ \\
\hline Helianthus neglectus (E-017) & $1.34 \mathrm{bc} \quad(100)$ & $1.06 \mathrm{~d} \quad(79)$ & $0.36 \mathrm{~g} \quad(27)$ & $0.92 b$ \\
\hline H. petiolaris spp. petiolaris (E-142) & $0.73 e$ & $0.35 \mathrm{~g} \quad(48)$ & $0.11 \mathrm{~h} \quad(15)$ & $0.40 \mathrm{~d}$ \\
\hline Root dry weight (g) & Relative tolerance (\%) & Mean Sq & are: 0.065 & $\operatorname{LSD}_{0.05}: 0.06$ \\
\hline
\end{tabular}


At $25 \%$ field capacity for plant height, the highest relative tolerance was calculated for E-175. This genotype also had the highest number of leaves and relative tolerance to drought, while the lowest values were found in E-060 and E-142. The highest shoot fresh weight and relative tolerance in extensive drought treatment were observed in E-060. The genotypes E-142 and E-017 had the lowest shoot fresh weight and relative tolerance to drought. The root fresh weight of all genotypes was dramatically decreased by the $25 \%$ field capacity treatment. The highest shoot dry weight and relative tolerance to drought were obtained from E-175. This genotype also had the highest root dry weight and relative tolerance at the highest drought treatment. In the case of root dry weight, E-175 was tolerant to extensive drought about $75 \%$ more than E-142 and E-060.

The root to shoot ratio at $100 \%$ field capacity was the highest in E-174 and E142. In drought treatments the highest ratios of root to shoot were observed in E174 and E- 175 at $75 \%$ field capacity and in E-175 and E-017 at $25 \%$ field capacity. E-142 had lower root to shoot ratios in drought conditions and the second highest value at $100 \%$ capacity.

The results show that E-175 (Helianthus annuus) had the highest resistance to drought, while E- 173 (Helianthus annuus) was the second genotype for resistance to drought. E-142 belonging to $H$. petiolaris spp. petiolaris showed the lowest resistance to drought. This genotype was followed by E-60 (Helianthus annuus) for high sensitivity to drought.

Table 2: Water capacity of root and shoot in treatments

\begin{tabular}{lcccc}
\hline \multirow{2}{*}{ Wild sunflower genotypes } & \multicolumn{2}{c}{ Water content (\%) of root } & \multicolumn{2}{c}{ Water content (\%) of shoot } \\
\cline { 2 - 5 } & $\begin{array}{c}100 \% \text { field } \\
\text { capacity }\end{array}$ & $\begin{array}{c}25 \% \text { field } \\
\text { capacity }\end{array}$ & $\begin{array}{c}100 \% \text { field } \\
\text { capacity }\end{array}$ & $\begin{array}{c}25 \% \text { field } \\
\text { capacity }\end{array}$ \\
\hline Helianthus annuus (E-60) & 97.53 & 94.26 & 68.21 & 79.20 \\
Helianthus annuus (E-173) & 90.67 & 79.90 & 64.62 & 34.75 \\
Helianthus annuus (E-174) & 94.10 & 85.21 & 70.22 & 41.18 \\
Helianthus annuus (E-175) & 93.43 & 78.01 & 64.23 & 19.58 \\
Helianthus neglectus (E-017) & 92.30 & 84.61 & 59.97 & 23.13 \\
H. petiolaris spp. petiolaris (E-142) & 97.34 & 94.18 & 81.09 & 57.61 \\
\hline
\end{tabular}

The water contents of root and shoot belonging to wild sunflower genotypes at $100 \%$ field capacity and $25 \%$ field capacity are shown in Table 2 . In no stress conditions, the highest water content of root was observed in E-142 (Helianthus petiolaris ssp. petiolaris), while E-173 had the lowest water capacity. At $25 \%$ field capacity, the resistant genotypes lost their water content more than the sensitive ones. Water decreases of root in E-175 and E-173 were $15.42 \%$ and $10.86 \%$, respectively. The water capacity of sensitive genotypes decreased minimally by $3.16 \%$ and $3.27 \%$ in E-142 and E-60, respectively. Similar water losses were observed for shoot water capacity. Shoot water losses of the resistant genotypes were also higher than those of the sensitive genotypes. The water capacity of shoot of E-175 was reduced by $44.65 \%$, while E-142 had $23.48 \%$ water losses. Water 
losses of the resistant genotypes in their roots and shoots in drought stress conditions were more than those of the sensitive genotypes.

Table 3: Comparison of the effect of drought on sunflower cultivars grown in vivo

\begin{tabular}{lccccc}
\hline & Plant height & $\begin{array}{c}\text { Number of } \\
\text { leaves }\end{array}$ & $\begin{array}{c}\text { Fresh shoot } \\
\text { weight }\end{array}$ & $\begin{array}{c}\text { Fresh root } \\
\text { weight }\end{array}$ & Dry shoot weight \\
\hline Fresh shoot weight & $0.8417^{\star *}$ & $0.8382^{\star *}$ & & & \\
Fresh root weight & $0.9427^{\star *}$ & $0.9410^{\star *}$ & $0.8456^{\star *}$ & & \\
Dry shoot weight & $0.8293^{*}$ & $0.8582^{\star *}$ & $0.8093^{\star *}$ & $0.8238^{\star *}$ & \\
Dry root weight & $0.8129^{\star *}$ & $0.8569^{\star *}$ & $0.7567^{\star *}$ & $0.7843^{\star *}$ & $0.8904^{* *}$ \\
\hline
\end{tabular}

** Significant at 0.01

The correlation analysis among values of plant characters obtained from wild sunflower genotypes under drought treatments in vivo is shown in Table 3. Although all correlations were significant at the 0.01 statistical level, the highest means of correlation coefficients were observed for the number of leaves, followed by fresh root weight and plant height.

Previous studies on drought effects in wild sunflowers produced similar results. During vegetative development, drought reduced the main stem height, stem diameter, number of nodes or leaves and leaf area (Agele, 2003). The reduction in vegetative biomass resulted in lower plant surface area, which reduced the radiation use efficiency and photosynthetic activities (Stockle and Kiniry, 1990; Badr et al., 2004; Germ et al., 2005). Other studies showed that $H$. annuus accumulated three times more dry matter per plant than $H$. petiolaris irrespective of water stress (Sobrado and Turner, 1983; Sobrado, 1986).

As the result, the most tolerant wild sunflower genotype within the six wild sunflower genotypes was E-175 (wild Helianthus annuus). E-142 (H. petiolaris spp. petiolaris) was the most sensitive genotype to extensive drought. In the lower drought treatment, E-174 (wild Helianthus annuus), E-017 (Helianthus neglectus), and E-175 (wild Helianthus annuus) were more resistant than the other genotypes. In the drought treatment at $75 \%$ field capacity, E-60 (wild Helianthus annuus) had the highest sensitivity. In addition, this study showed that the number of leaves and root weight were the best selection criteria to determine drought resistance at early vegetative stage. It is necessary to evaluate a large number of populations of wild Helianthus species to find new genes for abiotic stress resistance to transfer hybrids.

\section{ACKNOWLEDGEMENT}

This article was submitted from the master's thesis Gucer, T., Determination of Morphologic, Physiologic Features of Some Wild Sunflower and Search Hybridization Facilities with Cultural Sunflower, Namik Kemal University, Graduate Schooll of Natural and Applied Science, Tekirdag, Turkey 78 p (2009). 


\section{REFERENCES}

Agele, S.O., 2003. Sunflower responses to weather variations in rainy and dry, cropping seasons in a tropical rainforest zone. International Journal of Biotronics 32: 17-33.

Albuquerque, F.M.C. de and Carvalho, N.M. de, 2003. Effect of type of environmental stress on the emergence of sunflower (Helianthus annuus L.), soyabean (Glycine max (L.) Merril) and maize (Zea mays L.) seeds with different levels of vigor. Seed Sci. Technol. 31: 465467.

Ashraf, M. and Mehmood, S., 1990. Response of four Brassica species to drought stress. Environ. Expt. Bot. 30: 93-100.

Badr, N.M., Thalooth, A.T. and Mohamed, M.H., 2004. Effect of foliar spraying with the nutrient compound "Streen" on the growth and yield of sunflower plants subjected to water stress during various stages of growth. Bulletin of the National Research Centre Cairo 29(4): 427-439.

Baldini, M., Vannozzi, G.P., Berville, A. and Tersac, M., 1999. Yield relationships under drought in sunflower genotypes obtained from a wild population and cultivated sunflowers in rainout shelter in large pots and field experiments. Helia 22(30): 81-96.

Bilski, J.J., Nelson, D.C. and Conlon, R.T., 1988. Response of six wild potato species to chloride and sulphate salinity. American Potato Journal 65: 605-612.

Bošnjak, D.J., 2004. Drought and its relation to field crops production in Vojvodina Province (Serbia, Serbia \& Montenegro). Zbornik radova. Naučni institut za ratarstvo i povrtarstvo (Serbia and Montenegro) 40: 45-55.

Campos, H., Cooper, M., Habben, J.E., Edmeades, G.O. and Schussler, J.R., 2004. Improving drought tolerance in maize: a view from industry. Field Crops Research 90: 19-34.

Edmeades, G.O. and Bänziger, M., 1997. Conclusion: What have we learned and where do we go? In: Edmeades, G.O., Bänziger, M., Mickelson, H.R., Penavaldiva, C.B. (Eds.), Developing Drought and Low N-Tolerant Maize. Proceedings of a Symposium, March 25-29, 1996, CIMMYT, El Batan, Mexico. Mexico, D.F. pp. 557-563.

Fereres, E., Gimenez, C. and Fernandez, J.M., 1986. Genetic variability in sunflower cultivars under drought. I. Yield relationships. Australian Journal of Agricultural Research 37: 573-582.

Fick, G.N. and Miller, J.F., 1997. Sunflower Breeding. In: Schneiter, A.A., (ed), Sunflower Technology and Production. ASA. Inc., CSSA, Inc., SSSA, Inc., Publishers. Madison. Wisconsin, USA. pp. 395-441.

Gajri, P.R., Gill, K.S., Chaudhary, M.R. and Singh, R., 1997. Irrigation of sunflower (Helianthus annuus) in relation to tillage and mulching. Agricultural Water Management 34(2): 149160.

Germ, M., Berčič, O.U. and Ačko, D.K., 2005. The response of sunflower to acute disturbance in water availability. Acta Agriculturae Slovenica 85: 135-141.

Gucer, T., 2009. Determination of morphologic, physiologic features of some wild sunflower and search hybridization facilities with cultural sunflower. Master thesis, Namik Kemal University, Graduate Schooll of Natural and Applied Science, Tekirdag, Turkey pp. 1-78.

Iqbal, N., Ashraf, M., Ashraf, M.Y. and Azam, F., 2005. Effect of exogenous application of glycinebetaine on capitulum size and achene number of sunflower under water stress. International Journal of Biology and Biotechnology 2(3): 765-771.

JMP software-data analysis statistics, 2005. SAS Institute Inc. North Caroline

Kiani, P.S., Grieu, P., Maury, P., Hewezi, T., Gentzbittel, L. and Sarrafi, A., 2007. Genetic variability for physiological traits under drought conditions and differential expression of water stress-associated genes in sunflower. Theor Appl Genet. 114(2): 193-207.

Rauf, S., 2008. Breeding sunflower (Helianthus annuus L.) for drought tolerance. Communications in Biometry and Crop Science 3(1): 29-44.

Reddy, G.K.M., Dangi, K.S., Kumar, S.S. and Reddy, A.V., 2003. Effect of moisture stress on seed yield and quality in sunflower (Helianthus annuus L.). Journal of Oilseeds Research 20(2): 282-283.

Seiler, G.J., 2007. The potential of wild sunflower species for Industrial uses. Helia 30(46): 175-198.

Singh, B.D., 2000. Plant breeding-principles and methods. Kalyani Publishers. Ludhiana, New Delhi, Noida, India, pp. 1-896.

Škorić, D., 2009 Sunflower breeding for resistance to abiotic stresses. Helia 32(50): 1-16. 
Sobrado, M.A. and Turner, N.C., 1986. Photosynthesis, dry matter accumulation and distribution in the wild sunflower Helianthus petiolaris and the cultivated sunflower Helianthus annuus as influenced by water deficits. Acta Oecologia 69: 181-187.

Stockle, C.O. and Kiniry, K.R., 1990. Variability in crop radiation-use efficiency associated with vapour-pressure deficit. Field Crops Research 25: 171-181.

Turhan, H. and Baser, I., 2004. In vitro and in vivo water stress in sunflower (Helianthus annuus L.). Helia 27(40): 227-236.

Yordanov, I., Velikova, V. and Tsonev, T., 2000. Plant responses to drought, acclimation, and stress tolerance. Photosynthetica 38: 171-186. 
